\title{
Pengembangan media pembelajaran fisika berbentuk buletin pada materi usaha dan energi di SMA Negeri 2 Laung Tuhup
}

\author{
Rashtria Azizah Utami a, 1*, Mukhlis Rohmadi ${ }^{\text {b, } 2}$, Nurul Septiana ${ }^{\text {c, } 3}$ \\ a,b,c IAIN Palangka Raya, Jl. G. Obos Kompleks Islamic Center Palangka Raya, Kode Pos 73112 \\ ${ }^{1}$ rashtriaazizahu@gmail.com*; mukhlis.rohmadi@gmail.com; mbak.septi@gmail.com \\ *korespondensi penulis
}

Received: 18 Agustus 2021

ARTICLE HISTORY

Revised: 3 Februari 2022

Accepted: 25 Februari 2022

\begin{abstract}
ABSTRAK
Penelitian yang berjudul Pengembangan Media Pembelajaran Fisika Berbentuk Buletin Pada Materi Usaha dan Energi di SMA Negeri 2 Laung Tuhup bertujuan untuk 1) mengembangkan sebuah media pembelajaran fisika berupa media cetak berbentuk buletin, 2) mengetahui tingkat kelayakan media pembelajaran berdasarkan hasil validasi para ahli media dan materi, 3) mengetahui tanggapan guru dari kelayakan media sebelum di uji cobakan di lapangan. Jenis penelitian yang digunakan yaitu R\&D dengan metode yang digunakan adalah ADDIE dengan lima tahap yaitu (1) Analysis (2) Design (3) Development (4) implementation (5) Evaluation. Namun penelitian yang dilakukan ini hanya sampai pada tahap ketiga saja yaitu tahap Development atau pengembangan. Data diperoleh dari dua orang dosen sebagai validasi ahli materi, dua orang dosen sebagai validasi ahli media, dan satu orang guru pembelajaran fisika di sekolah tempat penelitian. Hasil pengembangan media pembelajaran diperoleh nilai persentase total dari kedua validator ahli media pembelajaran sebesar $97 \%$ kategori sangat baik, hasil penilaian kedua validator ahli media mendapatkan hasil 95,2\% kategori sangat baik, dan hasil penilaian guru fisika memperoleh nilai sebesar $98 \%$ dengan kategori sangat baik. Berdasarkan hasil penelitian ini dapat disimpulkan bahwa media pembelajaran dapat dan layak digunakan sebagai media pembelajaran pada materi usaha dan energi.
\end{abstract}

Kata kunci : media pembelajaran, buletin, usaha dan energi

ABSTRACT

Development of physical learning media in bulletins on work and energy materials at SMA Negeri 2 Laung Tuhup. The research entitled Development of Physics Learning Media in the form of Bulletins on work and Energy Materials at SMA Negeri 2 Laung Tuhup aims to develop a physics learning media in the form of bulletin printed media, determine the feasibility level of learning media based on the validation results of media and material experts, knowing the teacher's response to the feasibility of the media before being tested in the field. The type of research used in R\&D, with the method used is ADDIE with five stages, namely (1) Analysis (2) Design (3) Development (4) implementation (5) Evaluation. However, this research has only reached the third stage, namely the development stage. Data were obtained from two lecturers as material expert validation, two as media expert validation, and one physics teacher at the school where the research was conducted. The results of the development of learning media obtained the total percentage value of the two learning media expert validators of $97 \%$ in the excellent category, the results of the assessment of the two media expert validators obtained $95.2 \%$ in the excellent category, and the results of the assessment of the physics teacher obtained a score of $98 \%$ in the very good. Based on the results of this study, it can be concluded that learning media can and are feasible to be used as learning media on work and energy materials.

Key word: Keyword 1, Keyword 2, Keyword 3, Keyword 4

\section{Pendahuluan}

Pendidikan adalah sebuah proses bagi setiap individu yang mempengaruhi dirinya sebagai seorang peserta didik dalam menyesuaikan diri terhadap lingkungan, melalui perubahan tersebut sehingga menjadikannya berfungsi bagi kehidupan di masyarakat (Hastuti \& Tiatri, 2012; Subagyo, 2015), pendidikan juga dikatakan sebagai pengembangan potensi diri, kemampuan, kapasitas yang dipengaruhi oleh kebiasaan, pendidikan yang didukung dengan kebiasaan baik dan dibantu dengan sebuah alat atau media yang telah dirancang dan disusun sedemikian rupa sehingga proses dalam pendidikan dapat mencapai tujuan seperti yang telah diharapkan (Suwarno, 2006).

Pendidikan yang dapat dikatakan efektif jika didalam proses pendidikan dapat menciptakan suasana belajar yang nyaman, yang memungkinkan peserta didik mudah dalam mengikuti proses pembelajaran, memudahkan peserta didik memahami pembelajaran sehingga dapat mencapai tujuan pembelajaran seperti yang diharapkan (Rochmat, 2009). 
Pendidikan bisa didapatkan dengan berbagai macam salah satunya pendidikan formal yaitu pendidikan di sekolah, salah satu pendidikan di sekolah yaitu adanya interaksi guru dengan peserta didik. Guru sebagai panutan di sekolah dan juga sebagai pelaksana kurikulum sekolah harus mengerti dengan kebutuhan setiap peserta didik, guru dituntut menyesuaikan dengan teknik mengajar yang digunakan dalam pembelajaran (Sulistyorini, 2009).

Sebuah alat bantu yang dapat digunakan guru dalam mencapai tujuan pembelajaran dinamakan media pembelajaran. Pada zaman yang semakin canggih ini media pembelajaran banyak sekali macamnya, namun tanpa menghiraukan budaya baru dan pembelajaran tidak hanya terpaku menggunakan gadget yang telah berbagai macam jenisnya tanpa memperhatikan lagi budaya membaca. Ada berbagai macam media pembelajaran yang bisa guru gunakan dalam membantu proses belajar di sekolah, media pembelajaran di klasifikasikan menjadi tujuh, yaitu (1) media audio visual gerak, (2) media audiovisual diam, (3) media visual gerak, (4) media visual diam, (5) media semi gerak, (6) media audio, (7) media cetak (Suwarna et al, 2006).

Media adalah sebuah alat untuk menyalurkan pesan dari seorang pengirim kepada penerima sehingga dapat merangsang pikiran, meningkatkan minat dan menimbulkan perasaan dan perhatian peserta didik dalam pembelajaran sehingga proses pembelajaran terjadi (Sadiman et al, 2010). Sehingga menurut (Arsyad, 2009) media pembelajaran merupakan sebuah media bertujuan untuk menyampaikan pesan ataupun informasi dengan instruksional atau mengandung maksud pengajaran.

Berdasarkan hasil observasi dan wawancara dengan salah seorang guru mata pelajaran fisika yang mengajar di SMAN 2 Laung Tuhup, diperoleh hasil bahwa pembelajaran dikelas belum pernah menggunakan media pembelajaran selain buku paket dan buku guru. Selain itu pada mata pelajaran fisika yang dirasa sulit oleh peserta didik terutama pada materi usaha dan energi. Guru juga hanya menggunakan metode ceramah dengan disertai peserta didik untuk menjawab soal pada setiap akhir pembelajaran berlangsung. Hai tersebut menimbulkan rasa bosan dan malas pada peserta didik dalam pembelajaran ditambah dengan tidak ada media sebagai penunjang pembelajaran yang mengakibatkan peserta didik membaca buku pelajaran karena dirasa kurang menarik dan kesulitan memahami konsep dan rumus-rumus pada materi usaha dan energi. Hal ini didapatkan dari angket analisis kebutuhan peserta didik yang menyatakan bahwa $80,6 \%$ peserta didik merasa kesulitan dalam mempelajari mata pelajaran fisika, dan 93,5\% peserta didik membutuhkan bahan bacaan lain sebagai alternatif belajar fisika. Salah satu media pembelajaran yang dapat digunakan sebagai alternatif meningkatkan minat dan motivasi belajar peserta didik adalah media buletin.

Buletin adalah terbitan berkala berbentuk selebaran buku yang diterbitkan secara teratur oleh organisasi memuat publikasi terkait dengan pemberitahuan yang berguna bagi khalayak tertentu (Risnawati, 2015). Buletin memiliki peran dan fungsi sebagai penyebar informasi ilmiah, mendidik, dan juga sebagai kontrol sosial. Buletin dapat dijadikan sebagai salah satu alternatif cara untuk meningkatkan minat baca dan meningkatkan pemahaman peserta didik dalam pembelajaran (Fadhil, 2016). Pemilihan buletin sebagai media pembelajaran didasarkan pada kelebihan yang dimilikinya yaitu dapat menstimulus peserta didik dalam meningkatkan minat membaca, sebagai sarana komunikasi dan menambah pengetahuan (sani et al). Bahasa yang digunakan di dalam buletin komunikatif, mudah dipahami, dan disertai pemilihan warna yang menarik sehingga peserta didik mudah dalam memahami isi bacaan.

Penelitian tentang media buletin dapat dilihat dari penelitian (Putri et al 2015), dari hasil penelitian oleh ahli materi, ahli media, guru fisika, dan respons peserta didik menunjukkan hasil bahwa media pembelajaran buletin dikategorikan baik dan layak digunakan dengan beberapa revisi keterlaksanaan hasil belajar dan ketercapaian hasil belajar. Selain itu penelitian dari Retno et.al (2015), mendapatkan hasil dari media pembelajaran buletin yang dikembangkan berupa buku saku dinilai praktis dengan bentuk yang kecil beserta kegunaannya sebagai sumber belajar mandiri, hasil dari nilai rata-rata siswa belajar kognitif mencapai nilai $86,60 \%$ yang dikategorikan baik. 
Berdasarkan penjelasan di atas, maka perlu dikembangkan media pembelajaran fisika berbentuk buletin materi usaha dan energi sebagai penunjang pembelajaran dan meningkatkan motivasi, minat baca dan meningkatkan minat belajar peserta didik.

\section{Metode}

Jenis penelitian yang dilakukan dalam penelitian ini yaitu $\mathrm{R} \& \mathrm{D}$ (Research and Development). Dengan metode yang digunakan yaitu ADDIE (Analysis, Design, Development, Implementation, and Evaluation). Pendekatan yang digunakan pada penelitian ini yaitu pendekatan kualitatif dengan jenis penelitian deskriptif. Penelitian kualitatif adalah sebuah penelitian menggunakan teknik analisis, observasi dan data lain sehingga menyajikan respons dan perilaku dar subjek (Setyosari, 2012). Penelitian yang dilakukan hanya berfokus pada tahap ketiga pada metode ADDIE yaitu sampai tahap (development) pengembangan.

Subjek pada penelitian ini yaitu dua orang dosen Fisika IAIN Palangkaraya sebagai ahli materi, dua orang dosen Fisika IAIN Palangkaraya sebagai ahli media, dan satu orang guru mata pelajaran fisika di sekolah. Instrumen yang digunakan berupa angket validasi dan lembar kelayakan media akan divalidasi sebelum kegiatan penelitian berlangsung. Sumber data pada penelitian ini terdiri dari angket yang akan di isi oleh validator media, materi, dan guru pembelajaran dengan memberikan tanda centang/cek $(\sqrt{ })$ pada skor yang telah disajikan.

Teknik analisis data menggunakan perhitungan seperti di bawah ini:

$$
N P=\frac{R}{S M} \times 100 \%
$$

Keterangan:

\begin{tabular}{llc} 
NP & : Nilai persen \\
R & : Skor mentah yang diperoleh \\
SM & : Skor maksimum ideal dari tes yang bersangkutan \\
& \multicolumn{2}{c}{ Tabel 1. Aturan pemberian skor } \\
\cline { 2 - 3 } & Skor & Kategori \\
\hline 4 & Sangat Baik \\
& 2 & Baik \\
& 1 & Cukup \\
& \multicolumn{2}{c}{ Sumber: Sugiyono 2017 }
\end{tabular}

Tabel 2. Kualifikasi Tingkat Kelayakan Berdasarkan Persentase Rata-rata

\begin{tabular}{ccc}
\hline Skor & Tingkat Pencapaian & Kualifikasi \\
\hline 4 & $81 \% \leq \times \leq 100 \%$ & Sangat Baik \\
3 & $61 \% \leq \times \leq 80 \%$ & Baik \\
2 & $41 \% \leq \times \leq 60 \%$ & Cukup \\
1 & $\leq 41 \%$ & Sangat Kurang \\
\hline
\end{tabular}

Sumber: Purwanto (2008)

\section{Hasil dan Pembahasan}

\section{Tahap analisis}

Tahap pertama yaitu analisis, peneliti melakukan wawancara tidak tertulis dengan guru mata pelajaran mengenai proses pembelajaran di sekolah, dan mendapatkan hasil bawa ketika pelajaran fisika berlangsung guru belum pernah menggunakan media pembelajaran sebagai penunjang proses pembelajaran, selain itu guru hanya menggunakan metode ceramah dan mengakhiri setiap 
pembelajaran dengan mengerjakan soal-soal. Kemudian pada tahap ini juga peneliti melakukan analisis kebutuhan pada peserta didik dengan mengirimkan pertanyaan-pertanyaan yang berkaitan dengan kebutuhan peserta didik melalui Google form. Hasil yang didapatkan yaitu sebanyak 80,6\% peserta didik kesulitan memahami materi fisika, 90,3\% peserta didik belum memiliki media pembelajaran selain buku paket, 93,5\%\% peserta didik membutuhkan media berupa media cetak Padahal 90,3\% peserta didik membutuhkan media untuk memperkuat pemahamannya. Dan juga 93,5\% peserta didik membutuhkan bahan bacaan lain sebagai bahan alternatif belajar fisika.

\section{Tahap desain/rancangan}

Tahap kedua yaitu perancangan/desain, pada tahap ini dilakukan perancangan produk yang akan dikembangkan pada materi usaha dan energi. Materi usaha dan energi dipilih sebagai media pembelajaran karena berdasarkan hasil angket dari Google form yang telah diisi oleh peserta didik. Media pembelajaran berbentuk buletin dibuat untuk penunjang pembelajaran dan dirancang dengan sedemikian rupa, dengan pemilihan warna, huruf, tata letak dan gambar-gambar pendukung yang menarik. Proses awal desain pada media ini menggunakan aplikasi MS Word 2013. Adapun tahapan dalam desain perancangan media pembelajaran buletin ini antara lain (1) Mengumpulkan informasi pendukung pada materi usaha dan energi sebagai penunjang isi dari media buletin yang akan dihasilkan, (2) membuat struktur media pembelajaran, (3) membuat storybord.

Isi materi pada media pembelajaran buletin dengan materi usaha dan energi adalah konsep yang dipertajam, diperluas, dan diperdalam dari buku-buku pelajaran yang digunakan di sekolah SMAN 2 Laung Tuhup fisika kelas X .Peneliti juga menambahkan konten dengan buku lain baik buku fisika terbitan lain, buku-buku fisika universitas, dan gambar-gambar penunjang dari internet.

\section{Tahap pengembangan}

Tahap selanjutnya yaitu membuat pengembangan media pembelajaran berbentuk buletin. Langkah pertama yang dilakukan yaitu menentukan indikator pembelajaran yang sesuai dengan kompetensi dasar pada materi usaha dan energi dengan mengacu pada kurikulum dan silabus yang digunakan di sekolah tempat penelitian. Pada tahap ini media pembelajaran berbentuk buletin yang akan dikembangkan terdapat perubahan berdasarkan saran dan masukan dari pembimbing dan validator.

\section{Validasi Ahli materi}

Tabel 3. Hasil Angket Penilaian ahli materi Validator 1 dan 2

\begin{tabular}{llccc}
\hline \multicolumn{1}{c}{ Indikator Penilaian } & $\begin{array}{c}\text { Nomor butir } \\
\text { penilaian }\end{array}$ & $\begin{array}{c}\text { Validator I } \\
(\boldsymbol{\%})\end{array}$ & $\begin{array}{c}\text { Validator II } \\
(\%)\end{array}$ & $\begin{array}{c}\text { Rata-Rata } \\
(\%)\end{array}$ \\
\hline $\begin{array}{l}\text { Kesesuaian materi dengan KI dan } \\
\text { KD }\end{array}$ & $1,2,3$ & 100,0 & 100,0 & 100 \\
$\begin{array}{l}\text { Kesesuaian Materi dengan } \\
\text { indikator dan tujuan pembelajaran }\end{array}$ & $4,5,6,7$ & 100,0 & 100,0 & 100 \\
$\begin{array}{l}\text { Kesesuaian dengan perkembangan } \\
\text { peserta didik }\end{array}$ & $8,9,10$ & 91,6 & 100,0 & 95,5 \\
Keakuratan materi & $11,12,13$, & 100,0 & 95,8 & 97,7 \\
Kemutakhiran materi & $15,16,17$ & & & \\
$\begin{array}{l}\text { Mendorong keingintahuan dan } \\
\text { Meningkatkan minat baca }\end{array}$ & $\begin{array}{l}18,19, \\
\text { Bahasa }\end{array}$ & $22,23,24$ & 100,0 & 93,7 \\
\hline
\end{tabular}


Berdasarkan pada hasil validasi materi media pembelajaran didapatkan hasil dari validator dan 2 total persentase sebanyak $97 \%$ yaitu termasuk dalam kualifikasi sangat baik. Terlihat pada setiap indikator penilaian bahwa setiap indikator tersebut validator memberikan nilai sangat baik dengan kriteria sangat layak digunakan sebagai media pembelajaran. Kriteria layak digunakan ini diberikan oleh kedua validator ahli dengan beberapa catatan perbaikan untuk menyempurnakan produk yang dihasilkan. Hal ini selaras dengan penelitian yang telah dilakukan oleh sari et al (2017) berdasarkan penilaian ahli mendapatkan hasil bahwa media pembelajaran buletin termasuk ke dalam kategori valid dan layak diujicobakan di lapangan. Selain itu penelitian lain juga dilakukan oleh Putri et al (2015) mendapatkan nilai sebesar 3,60 untuk penilaian dari ahli materi yang termasuk kategori sangat baik.

Validasi Ahli media

Tabel 4. Hasil Angket Penilaian ahli madia Validator 1 dan 2

\begin{tabular}{llccc}
\hline \multicolumn{1}{c}{ Indikator Penilaian } & \multicolumn{1}{c}{$\begin{array}{c}\text { Nomor Butir } \\
\text { Penilaian }\end{array}$} & $\begin{array}{c}\text { Validator I } \\
\mathbf{( \% )}\end{array}$ & $\begin{array}{c}\text { Validator II } \\
(\mathbf{\%})\end{array}$ & $\begin{array}{c}\text { Rata-rata } \\
(\mathbf{\%})\end{array}$ \\
\hline Ukuran Buletin & 1,2 & 100,0 & 100,0 & 100,0 \\
Desain sampul buletin & $3,4,5,6 \mathrm{a}$, & 100,0 & 100,0 & 100,0 \\
(Cover) & $6 \mathrm{~b}, 6 \mathrm{c}, 7$ & & \\
Desain Isi & $8 \mathrm{a}, 8 \mathrm{~b}, 9,10$, & 100,0 & 71,4 & 85,7 \\
& $11,12 \mathrm{a}, 12 \mathrm{~b}$, & & \\
& $13 \mathrm{a}, 13 \mathrm{~b}, 14 \mathrm{a}$, & & \\
& $14 \mathrm{~b}, 14 \mathrm{c}, 14 \mathrm{~d}, 14 \mathrm{e}$ & \\
\hline
\end{tabular}

Hasil penilaian kelayakan media pembelajaran dapat dilihat dari tabel 4 penilaian validator 1 dan 2 dengan mendapatkan persentase total sebesar 95,2\% termasuk kedalam kualifikasi sangat baik dan termasuk ke dalam kategori sangat layak digunakan dengan beberapa catatan perbaikan sebagai penyempurnaan produk. Hal ini selaras dengan penelitian yang dilakukan oleh Asyari \& Silvia (2016) menyatakan bahwa hasil yang diperoleh dari nilai kelayakan media dari penelitiannya pengembangan media buletin IPA terpadu dalam bentuk buku saku mendapatkan hasil dari para ahli desain media sebesar 79,4\% kategori layak digunakan. Selain itu penelitian oleh Habibati et al (2019) mendapatkan hasil penilaian kelayakan media buletin sebesar $75 \%$ kategori layak.

\section{Penilaian Guru}

Penilaian yang diberikan pada guru pembelajaran berupa angket. Guru pembelajaran disini yaitu guru yang berasal dari sekolah tempat penelitian yaitu SMAN 2 Laung Tuhup. Uji coba kelayakan pada guru diberikan sebagai bahan pertimbangan pada kesempurnaan media pembelajaran sebelum diuji cobakan di lapangan atau sebelum digunakan sebagai bahan pembelajaran di kelas. Jika hasil yang didapatkan termasuk kedalam kategori baik maka media akan dipertahankan dan dilanjutkan untuk diuji coba pada kelas, sedangkan jika hasil media belum mendapatkan kategori baik maka media akan di direvisi dan diperbaiki lagi dan di tindak lanjuti sehingga memperoleh kategori baik. Hasil tanggapan guru pada media pembelajaran dapat dilihat pada tabel di bawah ini.

Tabel 5. Respons Guru

\begin{tabular}{|c|c|c|c|}
\hline Aspek & $\begin{array}{l}\text { Nomor Butir } \\
\text { Penilaian }\end{array}$ & Skor Total & $\begin{array}{c}\text { Persentase Rata-Rata } \\
(\%)\end{array}$ \\
\hline Materi & $1,2,3,4,5,6,7,8$ & 31 & 96,8 \\
\hline Bahasa & $9,10,11,12$ & 14 & 87,5 \\
\hline Penyajian & $13,14,15,16,17$ & 20 & 100,0 \\
\hline \multicolumn{3}{|c|}{ Persentase Skor Total } & 98 \\
\hline
\end{tabular}


Berdasarkan tabel 5 di atas hasil yang didapatkan dari tanggapan guru mata pelajaran fisika di sekolah memperoleh nilai persentase sebesar 98\% dengan kualifikasi sangat baik dan kategori sangat layak digunakan dan di uji cobakan di lapangan. Pada aspek materi guru memberikan nilai 3 pada penyajian sesuai dengan kemampuan berpikir kritis siswa dengan catatan perbaikan sedikit yaitu menyederhanakan kata-kata pada media buletin sehingga menciptakan kalimat yang dapat menimbulkan kemampuan berpikir kritis peserta didik. Pada aspek bahasa dalam butir penilaian bahasa yang komunikatif mendapatkan nilai 3 dengan catatan menghidupkan sedikit bahasa yang digunakan sehingga memalui media tersebut peserta didik dapat berkomunikasi dan lebih memahami isinya, kemudian penggunaan besar kecil huruf yang digunakan mendapatkan nilai 3 dengan catatan kurang konsisten dapat menggunakan besar kecil huruf pada media. Sedangkan pada aspek penyajian mendapatkan nilai sempurna dengan semua butir penilaian mendapatkan nilai 4.

\section{Simpulan}

Berdasarkan hasil penelitian yang dilakukan maka dapat disimpulkan bahwa Penelitian validasi ahli materi dan ahli media pada media pembelajaran berbentuk buletin materi usaha dan energi mendapatkan hasil dengan nilai validasi dari ahli materi yaitu sebesar 97\% dengan kualifikasi sangat baik dan kriteria sangat layak digunakan. Sedangkan penilaian oleh ahli media mendapatkan hasil 95,2\% termasuk kedalam kualifikasi sangat baik dan kriteria sangat layak digunakan sebagai media pembelajaran dikelas. Tanggapan guru pada media pembelajaran buletin mendapatkan hasil sebesar 98\% dengan kualifikasi sangat baik dan kriteria sangat layak digunakan sebagai media pembelajaran dan dapat di uji cobakan di lapangan/dikelas.

Adapun saran yang dapat diberikan berdasarkan dari penelitian yang dilakukan untuk perbaikan dan berguna untuk penelitian selanjutnya, Pembuatan media pembelajaran menggunakan MS Word lebih sulit karena banyak kendala dapat peletakan gambar dan sebagainya, alangkah lebih baiknya jika ingin membuat media pembelajaran cetak seperti media buletin ini menggunakan aplikasi edit lain seperti adobe photosop dan sejenisnya.

\section{Referensi}

Berisi referensi sesuai sitasi yang ada di dalam naskah publikasi dengan jumlah minimal 15 referensi. Arsyad, Azhar. 2009. Media Pembelajaran. Jakarta: PT Raja Grafindo Persada.

Asyhari A, Silvia, H. 2016. Pengembangan media pembelajaran berupa buletin dalam bentuk buku saku untuk pembelajaran IPA terpadu. Jurnal Ilmiah Pendidikan Fisika Al-BiRuNi05(1):113.

Fadhli B. 2016. Teknologi Pembelajaran, Landasan dan Aplikasinya. Jakarta: Erlangga

Habibati, M.Hasan. Nelva Rahmatul Fitri. Pengembangan Media Buletin Menggunakan Coreldraw X7 pada Materi Pencemaran Lingkungan. Jurnal Pendidikan Sains Indonesia. Vol.07 No. 01. Tahun 2019.

Hastuti, R., \& Tiatri, S. (2012). Pendidikan Karakter Oleh Guru (Studi Kasus di Sekolah Dasar Islam di Jakarta). Prosiding Seminar Nasional Psikologi Islam, 144-150

Purwanto, Ngalim, 2008. Prinsip-prinsip dan Teknik Evaluasi Pengajaran. Bandung: PT. Remaja Rosdakarya.

Putri, Nur Rizki, dkk. Mengembangkan Buletin Pembelajaran Fisika Pokok Bahasan Gerak Melingkar pada Siswa Kelas X IPA SMA Negeri Purworejo Tahun Pelajaran 2014/2015. Jurnal Radiasi Volume. Vol. 06 No. 1, tahun 2015.

Ratna Sari, Dina Rifari Handayani, Pramudya Dwi A.P, Pengembangan Buletin Mari Belajar IPA (MAPALA) Pembelajaran IPA Di MTs Negeri 2 Jember. Jurnal Pembelajaran Fisika. Vol. 6. No.1, Tahun 2017. 
Retno ATP, Saputro S, Utami B. 2015. Pengembangan media pembelajaran buletin dalam bentuk buku saku berbasis hierarki konsep untuk pembela

Riswanti, I. 2016. Media Buletin Dan Seni Mural Dalam Upaya Meningkatkan Pengetahuan Tentang Obesitas. Journal Of Health Education 1(1):62-70. http://journal.unnes.ac.id/sju/index .php/jhealthedu/

Rochmat, W. (2009). Pembelajaran yang Efektif, Efisien, dan Menarik Sesuai dengan Perkembangan Teknologi Modern. Seminar Pendidikan, 1-11.

Sadiman, Arief S, R Raharjo, Anung Haryono dan Rahardjito. 2010. Media Pendidikan. Jakarta: PT Raja Grafindo Persada.

Setyosari P. 2012. Metode Penelitian Pendidikan dan Pengembangan. Jakarta: Kencana

Subagyo. (2015). Pengembangan Kualitas Sumber Daya Manusia Pegawai Perusahaan Listrik Negara Rayon Tenggarong Kabupaten Kutai Kartanegara. E-Journal Ilmu Pemerintahan, 3(2), 10981112

Sugiyono, 2017. Metode Penelitian Pendidikan, Bandung: Alfabetha

Sulistyorini. 2009. Manajemen Pendidikan Islam. Yogyakarta: Teras.

Suwarna, Slamet, M., Raharja, S., Satunggalno, Lestari, B., Sukarna, I.M., Winarni, S., \& Prihadi. 2006. Pengajaran Mikro Pendekatan Praktis dalam Menyiapkan Pendidik Profesional. Yogyakarta: Tiara Wacana. 